\title{
Flora and Fauna in the Perspective of the Bajo Maritime Language and Culture Studies Language
}

\author{
Tajirah Umajjah ${ }^{1}$, Ikhwan M. Said ${ }^{2}$, Asriani Abbas ${ }^{3}$ \\ ${ }^{1,2,3}$ Cultural Studies Faculty, Hasanuddin University \\ *Corresponding author.Email: thajirahumajiah@gmail.com
}

\begin{abstract}
Bajo is a tribe that lives in the sea. The interaction pattern of the Bajo is on the sea which is the source of their life. The nomadic lifestyle (wandering or moving) made the Bajo feel a real change in their cultural life. The tribes who have a life with the sea since a long time ago, are scattered in eastern Kalimantan, Sulawesi, Nusa Tenggara, to the southern Philippines now. In anthropological or cultural literature, there are various theories regarding the relationship between language and culture. In terms of language, the Bajo tribe uses the Sama-Bajau language. The Sama-Bajau language is the name for the language used by the Bajo people, especially in the coastal areas of the eastern Indonesian archipelago. The object of research in this paper is flora and fauna from the perspective of the Bajo language in the Kolaka region of Southeast Sulawesi. The data relating to flora and fauna were collected using descriptive qualitative research methods. It was found that a few numbers of flora and fauna in the perspective of the Bajo language, dominantly use the letter ' $\mathrm{H}$ ' in their lexical expression and often absorb the language of the neighbouring tribes who live side by side with it, namely: Bugis, Makassar and Tolaki.
\end{abstract}

Keywords: Bajo tribe, flora, fauna, Bajo language

\section{INTRODUCTION}

Indonesia is a country with a variety of tribes, customs and cultures. One of the tribes that attracted the attention of researchers to get to know and study more deeply about social lifestyle, culture and language is the Bajo tribe. The Bajo tribe is a tribe that lives in the sea. The pattern of interaction of Bajo people is centred on the sea that is the source of their lives. Nomadic lifestyles (wandering or moving around) make people feel a real change in their culture and language. As a result, Bajo people find it difficult to show their true identity. Whereas identity as a social phenomenon that arises from the dialectic between individuals and society. Identity is formed by social processes, maintained, modified or reshaped by the social relations of society.

The identity of Bajo people has now become vague due to social change and development that occurs so quickly. In addition, globalization that strengthens every line of life makes people cannot withstand the flow of global change.
In Indonesia, research on Bajo people has a high interest lately, both from the point of view of anthropology, ecology, sociology, politics and economics. Not a few social scientists try to research the lives of Bajo people, issues of identity of Bajo people, and issues about the language of Bajo people. If you research Bajo people, it cannot be separated from the writings of Robert Zacot, an anthropologist, who examined the Bajo people in depth (The Bajo people on Nain Island, in North Sulawesi and Torosiaje, in Gorontalo). In particular, he looked at the lives of the Bajo people as a whole, at the time, roughly between the 1970s and 1990s. His research used purely ethnographic methods, and still saw people Bajo at that time who had not been affected by his identity as it is today.

Then, Suyuti [4], explained the changing meaning of "sama" (Bajo people) and "bagai" (not Bajo people). From this meaning, He identifies social changes that occur to the Bajo community, analysis of the changes here are related to the interaction of the Bajo people with non-Bajo people, especially the Bajo people in Kolaka, 
Southeast Sulawesi. The latest research on the Bajo people was carried out by Baskara, who examined the Bajo people who had adapted to the immigrant religion (Islam) so that an acculturation process occurred in the formation of the identity of the Bajo people. In his writings, Baskara describes in-depth the formation of the identity of the Bajo people with Islam.

Although many experts have examined the lives of the Bajo people, they do not touch on how the process of language hybridization in the rites of the Bajo life cycle today. The part that has not been studied is the research gap that will be discussed and revealed by this small study. This research will examine the process of language hybridization as part of globalization in the Bajo community. External (global) culture has influenced the rites of the Bajo life cycle, particularly in the village of Hakatutobu whose life is close to the mainland, as a result of development.

Hakatutobu Village is famous for its vast expanse of sea. As a village near the sea, of course, language speakers who live on the coast use more vocabulary related to the marine environment. They are more familiar with and create the names of fish, algae, corals, sand and all marine content [1]

People living in marine environments have a marine lexicon. All objects and activities that exist with humans are mostly known and recorded cognitively by the speech community. Stored in lexicons, verbal texts and their discourses [2]. However, the development of the times and technology has a great impact on the validity of the language with the term marine, many lexicons that are not even known by the speakers themselves. Especially young speakers, many of them are no longer familiar with some lexicons in the field of marine Hakatutobu coastal language, especially regarding the marine environment.

Lexicon is a component of language that contains all the information about the meaning and use of words the language, lexicon is also interpreted as vocabulary, lexeme collection, and includes what is meant by words, vocabulary structuring, use and storage of words and the process of word formation in a language. The lexicon that will be studied is the lexicon of flora and fauna in the marine environment of Hakatutobu village.

\section{Figure 1}

Bajo tribal settlement in Hakatutobu village

Figure 2

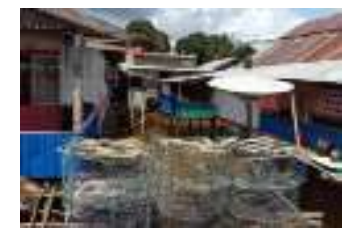

Bajo tribe catch in Hakatutobu village

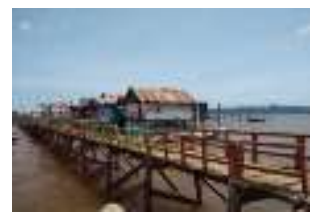

Hakatutobu village was chosen because of the background of writers who live adjacent to the village. Hakatutobu is a village in Pomalaa, one of Kolaka districts, Southeast Sulawesi province. The geographical location of Hakatutobu village is in the lowlands, the distance of the village with the sub-district capital is 10 $\mathrm{km}$, while the distance of the district capital is $36 \mathrm{~km}$. The state of society is dominated by Bajo tribes with livelihoods are fishermen. Every day, 175 heads of families depend on natural resources on the coast.

Hakatutobu has undergone a name change that was once called Kantobu in 1979, then, three years after it was renamed Kampung Baru. In 1988-1989, indigenous leaders in the village consulted to discuss their plans to make this area a village. In the meeting, the customary elders agreed to give this coastal name Hakatutobu which means a clump.

The Bajo tribe in Hakatutobu village uses the language "sama-bajau". The language "sama-bajau" is a language used by the people of Bajo tribe, especially in the coastal areas of the eastern Indonesian archipelago. This language is interesting because it has its dominant characteristics using the letters " $\mathrm{H}$ " and "O" at the end of the word. However, as the lifestyle, language and social development of the Bajo community, its language family, is now experiencing assimilation caused by the environment of residence and other tribes that live side by side with it around the coast. The tribes that live side by side with the Bajo tribe in Hakatutobu are Bugis, Makassar and Tolaki tribes.

Related to the coast, cannot be separated from the life of other living things such as flora and fauna (plants and animals). Flora and fauna in the bajo language perspective are objects in this study. Flora is all kinds of plants and plants that exist on the face of the earth. Fauna is any kind of animal that lives on earth. Flora and fauna have so many and diverse types that they are no longer numbered. Various animals and plants have diverse dwellings starting at sea or can also be on land.

In the sea flora, there is a wide variety of plants, especially seaweed. The oceans are full of plants and each contains a large group of different life forms. Some of them are so small that they can only be seen through a microscope. They have a varied way of life, some floating and others living glued to the sea or rocks, some can even repair some animals. They vary greatly depending on the temperature of the water in which they live.

Marine fauna is all that includes animals and living things in the sea, regardless of size. From the smallest such as protozoa to large vertebrates such as whales. They have several species, ranging from mammals such as dolphins, manatees, otters to birds, such as seagulls and pelicans, which we can even find infauna, molluscs, starfish and crustaceans. Turtles, although they belong to reptiles, are also part of marine fauna. 


\section{METHODOLOGY}

The type of research used to find out the lexicon of flora and fauna in the marine environment of Hakatutobu village is qualitative research. Qualitative research is the process of finding data to understand social problems based on thorough research, shaped by words and derived from natural situations. The data used in this study is data in the form of the lexicon of flora and fauna in the marine field. The data is sourced from oral data (kata) by conducting interviews with informants, namely fishermen and the customary chairman of the Bajo tribe in Hakatutobu village. While the secondary data comes from written documents related to the lexicon of the marine field in the Bajo language in Hakatutobu village.

To get complete data results, data collection is done in several ways, namely: (1) provides a synergy related to the lexicon of marine flora and fauna to respondents. The questionnaire was submitted to find out the level of knowledge of the Bajo community about the lexicon of marine flora and fauna in Hakatutobu village. (2) Researchers conduct interviews by asking questions directly to informants or research subjects regarding the lexicon of marine flora and fauna in Hakatutobu village. (3) Documents of written data related to research problems, namely lexicon of marine flora and fauna.

\section{ANALYSIS}

To analyze the data in this study, Miles, Huberman and Saldana data analysis techniques [3] are used which consists of four stages of activities that occur simultaneously, namely data collection, data condensation, data presentation and conclusion or verification. For more details, you can see the following steps:

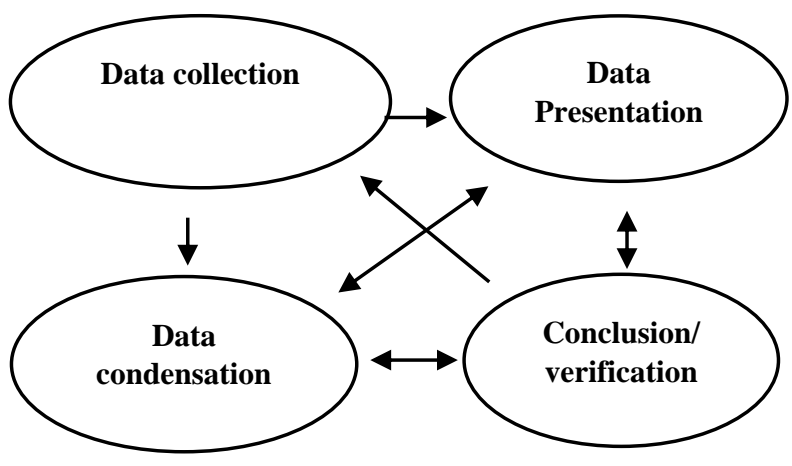

Figure 3: data analysis techniques: interactive models (Miles, Huberman, and Saldana, [3])

\section{FINDINGS}

The results of this study consist of two parts, namely (1) Flora in the perspective of the Bajo language and (2) the fauna in the perspective of the Bajo language. In this study, the data comes from a list of flora and fauna that live in the village of Hakatutobu.

\subsection{Flora in the perspective of the Bajo language}

The list of names of marine flora that live in Hakatutobu village is 19 data. The following is a lexicon list of marine flora that live in Hakatutobu village: (1) Algae, (2) Brown Algae, (3) Green Algae, (4) Red Algae, (5) Mangrove, (6) Cabomba, (7) Pond Cape, (8) phytoplankton, (9) Algae, (10) Brown algae, (11) Green algae, (12) Red algae, (13) Kelp, (14) Seagrass beds, (15) Posidonia, (16) grass sea, (17) soft coral, (18) Coral Reef, (19) Waterwheel.

The lexicon of marine flora in the Bajo language is seen in the following table.

Table.1: flora lexicon in the perspective of the Bajo language

\begin{tabular}{|c|c|c|c|}
\hline \multirow[t]{2}{*}{ No. } & \multicolumn{3}{|c|}{ TYPES OF SEA FLORA } \\
\hline & ENGLISH & LATIN & $\begin{array}{c}\text { BAJO } \\
\text { LANGUAGE }\end{array}$ \\
\hline 1. & Algae & Filum & Sasango \\
\hline 2. & Chocolate Algae & Filum phaeophyceae & Sasango Coklat \\
\hline 3. & Green Algae & Filum Charophyta & Sasango Nyulo \\
\hline 4. & Red Algae & Filum Rhodophyta & Sasango Mireh \\
\hline 5. & Mangrove & Rhizophora & Bangkao \\
\hline 6. & Cabomba & Caroliniana & Lumut \\
\hline 7. & Cape Pond & Ageratum & Babe \\
\hline 8. & Phytoplankton & phyton & Rutos \\
\hline 9. & Algae & Chrysophyceae & Lumut Halos \\
\hline 10. & Brown algae & Phaeophyceae & Lumut Coklat \\
\hline 11. & Green Algae & Chlorophyceae & Lumut Nyulo \\
\hline 12. & red algae & Rhodophyceae & Lumut Mireh \\
\hline 13. & Kelp & Enhalus & Daon Babe \\
\hline 14. & Seagrass meadow & Acoroides steud & Lalame \\
\hline 15. & Posidonia & Posidonia oceanica & Samo \\
\hline 16. & Seaweed & Gracilaria verrucose & Agar-agar \\
\hline 17. & Soft coral & Alcyonacean & Garas Mireh \\
\hline 18. & Coral reefs & Anthozoa & Garas \\
\hline 19. & Waterwheel Plant & Aldrovanda vesiculosa & Lato \\
\hline
\end{tabular}

\subsection{Fauna in the perspective of Bajo language}

The list of names of marine fauna that live in Hakatutobu village is 39 data. The following is a lexicon list of marine fauna that live in Hakatutobu village: Abalone, (2) Sea eel, (3) Starfish, (4) Squid, (5) Octopus, (6) Milkfish, (7) Barracuda Fish, (8) Rabbitfish, (9) Mullet, (10) Buntel Fish, (11) Skipjack Fish, (12) Yellow Tail Fish, (13) Julung-julung Fish, (14) Red Snapper, (15) White Snapper, (16) Bloated Fish, (17) Grouper, (18) Kite, (19) Napoleon Fish, (20) Stingray, (21) Whale, (22) Sardine, (23) Fish Tembang, (24) Mackerel, (25) Anchovy, (26) Tuna, (27) Tuna, (28) Crab, (29) kerrang, (30) seahorse, (31) Sea urchin/sea urchin, (32) Lobster, (33) Dolphin, (34) Turtle, (35) Sea Cucumber, (36) Oyster, (37) Jellyfish, (38) Shrimp and (39) Sea Snake.

The lexicon of marine fauna in the Bajo language is seen in the following table. 
Table.2: the lexicon of marine fauna in the perspective of the Bajo language

\begin{tabular}{|c|c|c|c|}
\hline \multirow[b]{2}{*}{ No. } & \multicolumn{3}{|c|}{ TYPES OF SEA FAUNA } \\
\hline & ENGLISH & LATIN LANGUAGE & $\begin{array}{c}\text { BAJO } \\
\text { LANGUAGE }\end{array}$ \\
\hline 1. & Abalon & Haliotidae & Bobokoigah \\
\hline 2. & Sea eels & Gymnothrorax Melegris & Ndoh Dilao \\
\hline 3. & Starfish & Filum Echinodermata & Kalangkah \\
\hline 4. & Squid & Cephalopoda & Kende \\
\hline 5. & Octopus & Filum Moluska & Kutta \\
\hline 6. & Milkfish & Chanos & Dayah Badah \\
\hline 7. & $\begin{array}{l}\text { Barracuda } \\
\text { fish }\end{array}$ & Sphyraena jello & $\begin{array}{c}\text { Dayah } \\
\text { Pangaluang }\end{array}$ \\
\hline 8. & Rabbitfish & Siganus & Dayah Birrah \\
\hline 9. & Catfish & Moolgarda seheli & Dayah Bonteh \\
\hline 10. & Buntel fish & Tetraodontidae & $\begin{array}{c}\text { Dayah } \\
\text { Konkeng }\end{array}$ \\
\hline 11. & $\begin{array}{l}\text { Skipjack } \\
\text { Tuna }\end{array}$ & Katsuwonus pelamis & Dayah Turinga \\
\hline 12. & $\begin{array}{c}\text { Yellow } \\
\text { Tailed Fish }\end{array}$ & Caesionidae & $\begin{array}{c}\text { Dayah } \\
\text { Kakambule }\end{array}$ \\
\hline 13. & The first fish & Hemiramphus Brasiliensis & Dayah Oras \\
\hline 14. & Red snapper & Lutjanus Campechanus & $\begin{array}{c}\text { Dayah } \\
\text { Bambangang }\end{array}$ \\
\hline 15. & $\begin{array}{c}\text { White } \\
\text { Snapper }\end{array}$ & Lates calcarifer & $\begin{array}{c}\text { Dayah } \\
\text { Salunsoh }\end{array}$ \\
\hline 16. & $\begin{array}{l}\text { Inflatable } \\
\text { Fish }\end{array}$ & Rastrelliger & $\begin{array}{c}\text { Dayah } \\
\text { Katombong }\end{array}$ \\
\hline 17. & Grouper fish & Epinephelus Coioides & Dayah Kerapu \\
\hline 18. & Ikan Layang & Decapterus & Dayah Lajang \\
\hline 19. & $\begin{array}{l}\text { Napoleon's } \\
\text { fish }\end{array}$ & Cheilinus undulates & $\begin{array}{c}\text { Dayah } \\
\text { Langkoe }\end{array}$ \\
\hline 20. & Stingray & Dasyatidae & Dayah Payi \\
\hline 21. & Whale & Cetacea & Dayah Basisau \\
\hline 22. & Sardines & Sardina Pilchardus & Dayah Kulli \\
\hline 23. & $\begin{array}{c}\text { Ikan } \\
\text { Tembang }\end{array}$ & Sardinella & Dayah Tebah \\
\hline 24. & Mackerel & Scomberomorini & Dayah Tangiri \\
\hline 25. & Teri Fish & Engraulidae & Dayah Lure \\
\hline 26. & Tuna & Euthynnus Affinis & $\begin{array}{c}\text { Dayah } \\
\text { Bankunes }\end{array}$ \\
\hline 27. & Tuna & Thunnini & Dayah Opo \\
\hline 28. & Crabs & Brachyura & Karama \\
\hline 29. & Shells & Anadara Granosa & Koah \\
\hline 30. & Seahorse & Hippocampus & Tandondo \\
\hline 31. & $\begin{array}{l}\text { Sea urchin / } \\
\text { sea urchin }\end{array}$ & Echinoidea & Tettehe \\
\hline 32. & Lobster & Nephropidae & Kalorah \\
\hline 33. & Dolphins & Euphrosyne & Lummu \\
\hline 34. & Turtle & Chelonioidea & Boko \\
\hline 35. & sea cucumber & Holothuroidea & Bale \\
\hline 36. & Oyster & Meretrix & Tirang \\
\hline 37. & Jellyfish & Scyphozoa & Bubbuloh \\
\hline 38. & Shrimp & Caridea & Doah \\
\hline 39. & Sea snakes & Hydrophiinae & Ndoh \\
\hline
\end{tabular}

\section{CONCLUSION}

The conclusions of the research lexicon of marine flora and fauna in the perspective of Bajo language in Hakatutobu village of Kolaka district of Southeast Sulawesi, are:

- The Bajo tribe is a nautical community that has the main activities at sea.

- The origin of the Bajo tribe is still an enigma to researchers because this tribe is found in several countries such as Indonesia, Malaysian and the Philippines.

- The Bajo language family is the "sama" language which then undergoes assimilation resulting from different residential environments.

- Flora and fauna in the Bajo language perspective predominantly use the letter ' $\mathrm{H}$ ' in its lexical expression.

- Several Bajo language lexicals absorb the language of their neighbour's tribe such as the Bugis, Makassar, and Tolaki tribes.

\section{AUTHORS' CONTRIBUTIONS}

The ideas in this paper were jointly formulated by authors 1, 2 and 3 in November 2020. The first author took the role of collecting data because the village of Hakatutobu is a village that is located side by side with the village where the first author lives, namely Pomalaa. In addition, the first author also has the task of being an interviewer and giving questionnaires to the informants. The second author played a role in the formulation of the instrument in the form of a questionnaire sheet and questions in the interview. The third author is in charge of translating the data and the entirety of this paper into English. The data analysis in this paper was carried out with the first, second and third authors.

\section{ACKNOWLEDGMENTS}

On this occasion, we would like to thank Mr Nurdin BSC as the village head of Hakatutobu who has given his permission and guidance in obtaining the data we need. We also thank the traditional chief of the Bajo tribe in Hakatutobu village who was so friendly and welcomed us well and provided very valid information regarding flora and fauna data in Hakatutobu village. and dear informants for the information that has been provided, we thank you very much.

\section{REFERENCES}

[1] Sapir, Edward. (2001). Language: An Introduction to the Study of Speech: New York Harcourt, Brace and Company.

[2] Mbete, Aron Meko. (2013). Penuntun Singkat Penulisan Proposal Penelitian Ekolinguistik. Denpasar: Vidia.

[3] Miles, Saldana \& Huberman, A. M. (2014). Qualitative Data Analysis-A Source of New Methodhs, Beverly Hill: SAGE Publisher, Ltd.

[4] Suyuti. H. Nasruddin (2001): Interaksi orang Bajo dan Orang Bugis dalam KonteksKearifan Lokal Global di Desa Sulaho Kabupaten Kolaka Utara Sulawesi Tenggara: Jagad Bahari Nusantara, Kementrian Kebudayaan dan Pariwisata Republik Indonesia. 